\title{
Management of the sustainable development of heating systems construction during changes of the conditions of the assessment
}

\author{
Natalia Verstina ${ }^{1}$ and Evgeny Evseev ${ }^{2}$ \\ ${ }^{1}$ Moscow State University of Civil Engineering, Yaroslavskoe shosse, 26, Moscow, 129337, Russia \\ ${ }^{2}$ Moscow Institute of Physics and Technology, 141700, 9, Institutskiy per., Dolgoprudny, Moscow \\ Region, Russia
}

\begin{abstract}
Scientific-and-practical aspects of regulating the matters of the assessment of sustainable development, are considered in the article. The tendencies of the heating systems development construction are systematized. The authors offer the methodical approach to the formation of information for the definition of indicators of sustainable development of heating systems construction in the built-up territories, taking into account the interrelation of the heating systems life cycle stages.
\end{abstract}

\section{Introduction}

Recently some normative documents (the standards of the EN 15643 series), harmonized with the standard foreign practice, which regulate the matters of the assessment of sustainable development of a construction projects on the basis of receiving quantitative estimates of its impacts on the ecological, social and economic conditions with the use of quantitative and qualitative parameters $[12,13,14,15]$, have been implemented in the Russian Federation. As for the latest publications on this matter, the main attention is paid to providing conditions for the sustainable development of such construction projects as buildings, while infrastructure facilities of any built-up territory are out of the zone of active consideration of the researchers $[27,18]$. At the same time, modern construction is characterized by the existence of a significant amount of infrastructure facilities, which includes the whole complex of the interconnected engineering structures and networks, providing the basis for comfortable and safe activity of population by the means of supply of industrial and civil facilities with different types of energy (heat, gas, electricity) and water and also by the means of removal of industrial, household and storm drains. Such infrastructure structures represent the network of some linearly extended facilities, which are mainly underground. The main cause is the profitability of the built-up space and the convenience of further maintenance of the facilities; but on the other hand, there are quite obvious difficulties during their maintenance [19, 28, 29, 22].

Heating systems, characterized by the most problem aspects of impact on the ecological, social and economic maintenance conditions of the built-up territory can be especially

Corresponding author: verstina@mail.ru 
noted among the infrastructure facilities of built-up territories of the modern cities. At the same time, the deterioration in indicators of these facilities maintenance is observed (even in the state scale); for the last 30 years the issue in the systems of the centralized heat supply has fallen almost twice. The essential surplus of power on the generating facilities was formed: The combined heat-and-power plant and boiler rooms are loaded respectively for $30 \%$ and $15 \%$ of their rated capacity. The quantity of problem small municipal boiler rooms under maintenance has been constructed since 2000, and that has increased their number more, than by $20 \%$. The quantity of the boiler-rooms, put into operation and burning natural gas has grown more than by 1.5 times. All that leads to some annual negative economic consequences: unproductive expenses because of the over-burning fuel at power plants (over 30 million tons of the equivalent fuel in a year), that negatively effects on the ecology of the built-up territories, and brings risks into the social sphere. Another problem for their sustainable development of the infrastructure facilities of the built-up territories are the heating systems, transporting heat. Their depreciation, caused by poor quality of construction by the acceleration of obsolescence of these facilities grows: about $70 \%$ of the heating systems work with the excess of standard service life, the accident rate in the heating systems has increased by $45 \%$ for the period from 2007 to 2013 and the rates is getting higher.

Thus, at the level of the general statement of the problem and separate tasks of the research a new perspective of perception of this perspective appears: that is providing the ways of sustainable development of the heating systems of the built-up territories, taking into account the current situation, which will allow to overcome the available negative tendencies in this branch $[1,3,4,10,11,23,24,20]$. The relevance of the ideas of sustainable development management increases, owing to the fact, that the directions of the improvement of construction projects for the power branch, according to the Forecast of scientific and technological development of branches of power industry of Russia until 2035 [6]. The document sets the key question of consecutive technological updating of power facilities, which construction has to be carried out on the basis of new design decisions, progressive constructive materials and technologies of construction. Besides, the forecast also considers the change in the long term of the character of construction of other projects of the built-up territories, changing the environment of the humans' activity as well as the requirements to infrastructure power supply facilities.

\section{Materials and Methods}

For making reasonable managerial decisions on ensuring sustainable development of construction of the heat supplying facilities, considered on the example of heating systems, and definitions of instruments for these processes management some tendencies, concerning construction of this type of facilities were considered in this research. The researches prove the existence of a significant gap between the negative phenomena in construction of facilities (heating systems) and the new requirements of this branch, connected with the enforcement of the staticized law on heat supply, which is cardinally changing requirements to ecological, social and economic terms of heat delivery of in the built-up territories.

The negative tendency of transition of technical condition of the heating systems because of their natural aging and the allowed defects in the course of construction to the critical condition at the following stage of the life cycle (the maintenance phase) has been observed for several decades; at the same time the volumes of their replacement are unsatisfactory. According to official figures, nearly $30 \%$ of the heating systems under maintenance need replacement, at the same time the actual volumes of reconstruction and renovation are insufficient [25]. Level of losses in the heating systems reaches 20-30\%, that 
is almost four times higher, than in the European countries. On this background there is a rapid deterioration in reliability and quality of heat supply, there are social consequences: about $30 \%$ of inhabitants of apartment houses in our country complain of quality and lack of heat. An unresolved question is the preservation of practice of violation of the hydraulic modes of the heating systems.

It is proved, that the power needs the enormous amount of funds for its modernization. The current investments are insufficient. According to Rosstat, investments into the power industry and the centralized heat supply made up 87 billion roubles in 2014. At the same time their volume is annually reduced. This situation is forcedly compensated by the annual subsidies of the budgetary funds (not taking into account the subsidies for housing-andcommunal services), which make up about 150 billion roubles, while 200 billion roubles are necessary; that makes up about $13 \%$ of necessary gross revenue (ТПК) of the branch. The needs for investment resources are estimated to be more than 2.5 trillion roubles (until 2025). About one third of this sum is required for updating of shabby heating systems (main and municipal); about $40 \%$ of the sum is required for updating of sources of generation (boiler rooms and combined heat-and-power plant). Thus, an adequate integrated assessment (taking into account such a scale of the means demanded at the maintenance stage) is obvious.

Against the background of existence of such negative phenomena the positive tendency (gradual emergence of new developments among the technologies, capable to provide a breakthrough for the development) is observed at this stage of the heating systems life cycle. The ideas, formed in the beginning of the discussion on the problems of the sustainable development, which were carried out more than two decades ago, can be the starting moment. So, for the first time the definition of sustainable construction includes the thought of the identity of such construction with "the creation and responsible maintenance of the healthy artificial habitat based on the effective use of mineral resources as well as on the ecological principles" [30]. The expert community notes, that the technological improvement of the heating systems construction has already started; basing on the application of the available development of heat conductors of high factory readiness, on the use of modern locking-and-control devices and also on the introduction of intellectual control systems for the modes of functioning of the heating systems. Thanks to the installation of the system of operating remote control for the level of humidity of thermal isolation it becomes possible to reduce the accident rate of the heating systems and connected damages for the ecology cardinally. And improving the metering and control devices for the heat consumption it is possible to improve significantly the economic indicators of the relations between consumers and suppliers of heat (and to do it in real time).

Obtaining the greatest effect from the improvement of methods of regulation of the heat issue, design of the independent closed schemes of the heat supplying facilities connection with the installation of individual heating points, further improvement of constructional and heat-insulating materials and coverings of pipelines is predicted in the short and medium term [26]. Development of new functional coverings with low adhesion to rigidity salts, small roughness and high anticorrosive properties for the increase in service life of the heating systems and the decrease in their hydraulic resistance is planned for this purpose. It is proved, that the application of new technology solutions will allow to improve ecological, social and economic indicators of heating systems at two stages of their life cycle: during construction it allows to reduce time of laying of pipes by 3-4 times, and during maintenance it allows to increase the service life of the heating systems up to 30-40 years and more, to reduce heat losses during transportation to $2-5 \%$, to lower operational expenses by 5-9 times, and to lower repair expenses by 3 times. 
On the other hand, the of energy saving policy and the increase in the energy efficiency of the facilities construction can give other foreshortening of the solution problem of sustainable development, concerning the facilities to which delivery of heat is carried out. The decrease in heat consumption at the expense of new heat-insulating materials and architectural planning solutions and absolutely new technological concepts in construction of so called "passive house" and "house with zero energy consumption" are among the perspective developments. The thermal pumps allowing to use low-potential warmly anthropogenic (productions and sewage) and natural (heat of soil and atmospheric air) origins for heating of buildings and hot water supply for small consumers also enter practice. It is clear, that when carrying out any technological developments of innovative character it is important to have an opportunity to carry out their comparison with each other on the basis of definition of "functional equivalents" of certain elements of the heating systems. At the same time it is important to have objective information on the functions performance during the use of engineering systems and to define the direction of new developments on this basis.

Implementation of the staticized law on heat supply which defines the third tendency in this branch, significantly influencing instruments of management in the estimated prospect became important basis for the sustainable development of construction of heating systems in modern conditions. It consists in gradual transition to the new model of pricing, which has received the name "method of an alternative boiler room", in the long term of 10 years. The carried-out analysis proved, that in fact the crisis of sources of financing is observed: their former structure, when budgets of various levels of our country allocated funds for modernization and construction of power facilities, is impossible. For the last two decades the sharpness of problems stimulated the authorities in the heat supply sphere to make various efforts for their decision, but those efforts were insufficiently effective. $[2,5,7,8]$. Nowadays the search of opportunities of attraction of the private capital for financing of the programmes of construction of the power facilities, based on the new technologies, is relevant. But private investors practically had no incentives. Therefore the updating of the law on heat supply in 2017 seems to be very reasonable. It is expected, that in case of successful realization it will be possible to provide the reduction of the volume of investment into construction and repair of heating systems to $40 \%$ of the current requirement. At the same time by 2025 in case of introduction of the model of "the alternative boiler room" the attraction of 2.5 trillion roubles, invested into heat supply, the decrease in the annual load of the budget for subsidizing of the branch of heat supply by 150 billion roubles is planned, and the social aspect of the changes consists in the creation of new jobs (not less than 37 thousand jobs). In this regard there is the necessity of the existence of information for decision-making not only for a separate heat supplying facility or its constructive part, but also for the whole system of heat supply in general in the conditions of orientation to the sustainable development.

The tendencies of the development of construction of the heat supplying facilities, systematized in this research, are very versatile: according to sources of emergence, purposes, and the character of the process. However, the objectivity of their existence determines the need of search of any "common denominator" for the managerial decisions in the context of the happening changes, which lead to the sustainable development. The first step is obtaining information of "new quality", which is significantly differing from the standard information standard. According to the authors it is the very problem during making managerial decisions on providing the sustainable development of the heating systems construction in the built-up territory. 


\section{Results}

Initial point of the conducted research on the use of the ideology of GOST P 57274.12016/EN 15643-1:2010 (GOST) was the fact that in the conditions of high potential and availability of information technologies sustainable development of the heating systems construction cannot be full without the use of new quality of information and analytical base for making managerial decisions, taking into account the interrelation of stages of the heating systems life cycle. The specifics of the construction projects of this type, using mainly underground laying, demonstrates the need of accounting of the nature of interrelation of at least two stages of the life cycle of the facilities: laying of these infrastructure facilities of building and their maintenance.

The authors have already considered the creation of information and analytical base of the heating systems maintenance in their earlier works as the necessary condition of the sustainable development in the conditions of modernization and construction of facilities of heat supply [12]. In this regard the provisions of GOST P 57274.1-2016/EN 15643-1:2010 were analized. According to GOST "The assessment of indicators of the sustainable development of construction projects applies much information. The assessment can be defined for the facility in general, its parts, which can separately be operated or structural elements" [12]. Thus the following provisions in the context of requirements of GOST, making author's methodical approach, [12-15] have been created. According to the authors, the assessment in the practice of management is always considered in two aspects:

- assessment as the process of holding procedures of data processing of measurements, which needs to be carried out for receiving reliable information about the implementation of technical and functional requirements on the facility under maintenance;

- assessment as the result of holding procedures of data processing of measurements, received on the basis of processing of quantitative data on a certain technique for further definition of ecological, social and economic indicators, taking into account technical and functional requirements to the facility.

The starting point of the estimates according to GOST is delimitation of the evaluated facility in the system of heat supply. Its specifics are that boundaries are to be set taking into account the geographically distributed heating systems, thanks to which heat supply for some several of customers is carried out. The experience proves the existence of the significant differences in expansion, constructive decisions and maintenance conditions of the heating systems. Therefore it is offered to use the concept "a section of heating systems". That will be able to integrate efforts of the customer, a customer and. The section of heating system is characterized by the following: No. of a thermal network according to the diagram, pipe type (giving / reverse), No. or designation of the initial chamber (n), No. or designation of the finite camera $(\mathrm{k}$ ), distance from $\mathrm{N}$ or (to) (in meters to within 0.5 meters), expansion of defect (in metres with an accuracy of customer), No. of an element of a heat conductor on which the defect is revealed.

It is important to provide the comparability of results, thus the whole group of concepts is used: "functional equivalent", "the functional performance)", "the functional requirements and/or technical requirements", etc. For the description of the main functional requirements according to the assignment of the facility it is offered to use the system of qualifiers, which allows to group 50-100 separate functional and technical parameters, components of primary character, information on actual state of the heating systems, characterizing the type and the level of the functional capabilities of heating systems, set by the user and/or normative documents. As for management the concept of the functional capabilities (functionality), which makes it possible to estimate the suitability or usefulness of the use of the construction facility for the set purpose or for the set activities (provision the customers with heat). 
Taking into account the features of extension of the information-and-analytical basis for making managerial decisions on the sustainable development, explained in the offered methodical approach, some other principles and requirements of GOST, which allowed to create the following provisions, considering specifics of the heating systems life cycle have been developed. Life cycle of a construction facility is the centre of the GOST requirements, at the same time the assessment of different influences of economic, ecological and social character within the life cycle, (life cycle impact assessment LCIA) is aimed at the analysis and determination of the value of these influences for the production system. Some questions of influence of the construction stage of the heating system life cycle on the maintenance stage were considered for meeting these requirements. The core of the analysis was the assumption, that the capabilities (functionality) of this infrastructure facility of the built-up territory, considered in GOST, depend on the quality of installation and construction works. According to the developed qualifiers the analysis of correlations was carried out and the results, provided in Table 1 were received.

Table 1. Ponderability of failures of the heating systems D (in shares of units)

\begin{tabular}{|c|c|c|}
\hline Cause of failures & Corrosion failures & Not-corrosion failures \\
\hline \multirow{3}{*}{$\begin{array}{l}\text { Depending on the } \\
\text { quality of works on } \\
\text { laying of pipes }\end{array}$} & $\begin{array}{l}\text { 1. Distortions of elements or } \\
\text { their parts when mounting }\end{array}$ & $\begin{array}{l}\text { 1. Distortions of elements or their parts } \\
\text { when mounting }\end{array}$ \\
\hline & 2. Thaw from above & 2. Bad multiplexing of connections \\
\hline & 3. Leak of pipeline water & 3. Slag switching on in a welded seam \\
\hline \multirow[t]{3}{*}{ Independent } & $\begin{array}{l}\text { 4. Corrosion of the active heat } \\
\text { carrier }\end{array}$ & 4. Sagging of support \\
\hline & $\begin{array}{l}\text { 5. Existence of the wandering } \\
\text { currents }\end{array}$ & \multirow[t]{2}{*}{$\begin{array}{l}\text { 5. Increase in loading from the heat } \\
\text { carrier }\end{array}$} \\
\hline & 6. Neighbourhood of cables & \\
\hline
\end{tabular}

Assessment of the service life of a facility or a building structure, which shall be defined according to the rules, set in standards on the construction products and also in the rules and recommendations, provided in standards of the ISO 15686 series [16] is provided in GOST. The basic reason of decrease in the service life of heating systems and lowering of their functionality, which is combined with different influences of economic, ecological and social character are violations (failures and damages) arising in case of maintenance owing to different defects. They are divided into two groups in this research. The first group, connected to the development of corrosion processes on metal elements, is observed more often, and the second group, not connected to the consequences corrosions, but nevertheless presented in statistics of researches, have the reasons of not corrosion character. Fistulas and gaps, which make $75-90 \%$ of the total number of failures of the heating systems, belong to violations of corrosion character. They are met on all the elements of the systems made of metal: pipelines, accessories, compensators, etc. For estimation of correlation of corrosion failures with the quality of installation and construction works the systematization was carried out and seven groups of the reasons, causing corrosion failures among which four groups are the consequence of low-quality performance of work in case of the heating systems construction were selected. The quality of such operations as waterproofing of walls and seal of seams of channels, chambers is the most essential. About $60 \%$ fall to the share of failures by such operations on average; the second and third place by quantity of failures is taken by the operations on the device of passing drainage, sandy base. The research proves, that, also violation the requirement to the quality of welding and installation works influences on the appearance of corrosion failures, therefore the tightness of multiplexing of elements is not provided and the leak in connections appears.

The failures of not corrosion character, which are observed, mainly, in wired logic connections, the locking regulating accessories, belong to the second group. As the result of 
systematization four types of not corrosion failures are named: deformations of elements or their parts, violations of tightness of multiplexing (connections), gaps without corrosion, and other malfunction of elements (specific). The causes of the appearance of failures which depend on the quality of a spacer of the heating systems are set: latches, valves, compensators having the difficult constructive device. In general the analysis of causes of the failures of heating systems proved, that up to $80 \%$ of the total number of failures is caused by the quality of installation and construction works. In this regard there are some questions, connected with the opportunities of extension of the information-and-analytical basis of the managerial decision making for the sustainable development in the direction of transition to the quantitative estimates.

\section{Discussions}

According to the provisions of methodical approach, explained above some quantitative data on the heating systems functioning during the maintenance stages, which can form the basis for a further discussion and the use for estimates of economic, ecological and social character, according to GOST ideology was received. Taking into account specifics of correlation of two stages of the heating systems life cycle, which defines the functionality of these construction facilities, caused the need of considered it in correlation with the negative events - violations (failures and damages) during maintenance of engineering systems. The authors have already offered and formalized the universal character the index allowing to create information of new quality on the functioning heating systems on the basis of monitoring maintenance - "U", criticality of consequences of negative events. [21] Criticality represents a certain set of signs, which can be differentiated on three groups and are evaluated in ecological, social and economic aspects according to the basic principles of the sustainable development, set in ISO 15392 [17]. As the formalized index, it allows to provide the quantitative assessment of the development stability of the heating systems, basing on the uniform information, required by analyzed GOST. However, the indicators estimates for the separate heating systems, basing on the uniform information within the offered methodical approach, are to be defined in the long term independently and according to the GOST ideology, depending on the field of their application.

We will present the data, obtained as the results of the research, which reflect the specifics of this construction facility (heating systems) at the maintenance stage. They allow to specify the features of economic, ecological and social quantitative assessment of the heating systems, in the aspect of their maintenance. According to the offered qualifiers the quantitative data, concerning failures and damages of the heating systems were created for two analytical cut-offs:

- the first cut-off characterized the constructive solution of these construction facilities; the essential parameters, defining the functionality of the engineering system, is the spacer type and diameter of the pipeline;

- the second cut-off characterized maintenance conditions and the surrounding of the construction facility; the existence or absence of violations in the heating systems operation during the normative period of maintenance was the result.

As a general characteristic of the significance of failures and damages from the point of view of frequency of their origin the distribution of the causes of violations in the heating systems operation was considered; that is schematically provided in the Figure 1. 


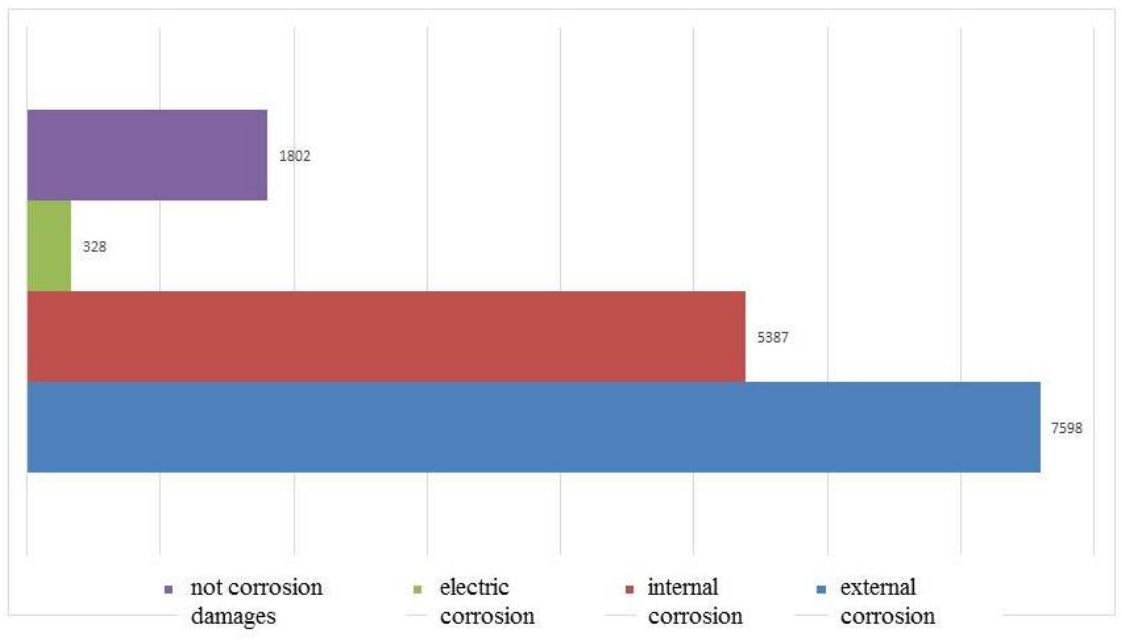

Fig. 1. Reasons of violations in heating systems work

For the all-round impact assessment of the quality of heating systems laying on its functionality during maintenance stage the speed the processes of corrosion at the giving and reverse pipelines was studied. The results provided in tables 1, 2 according to the types of a spacer and diameters on the example of the most "problem" outside corrosion.

Table 2. Speed of external corrosion (average) according to spacer types

\begin{tabular}{|c|c|c|c|c|c|}
\hline Spacer type & $\begin{array}{c}\text { Speed of } \\
\text { corrosion } \\
\text { [mm in a } \\
\text { year }]\end{array}$ & $\begin{array}{l}\text { Damaged } \\
\text { element of the } \\
\text { P2 pipe }\end{array}$ & $\begin{array}{l}\text { Corrosion } \\
\text { Speed [mm } \\
\text { in a year] } \\
\text { of the } \\
\text { P2 pipes }\end{array}$ & $\begin{array}{l}\text { Damaged } \\
\text { Element of the } \\
\text { P1 Pipe }\end{array}$ & $\begin{array}{l}\text { Corrosion } \\
\text { Speed } \\
\text { [mm in a } \\
\text { year] of } \\
\text { the } \\
\text { P1 pipes }\end{array}$ \\
\hline Channelless & 0.4 & bypass & 0.19 & bypass & 0.53 \\
\hline Sleeve/case & 0.53 & drainage & 1.2 & drainage & 0.17 \\
\hline $\begin{array}{l}\text { underwater } \\
\text { pipeline }\end{array}$ & 0.47 & cap & 0.6 & cap & 0.06 \\
\hline Chamber & 0.82 & latch & 0.41 & latch & 0,62 \\
\hline Collector & 0.62 & $\begin{array}{l}\text { line of } \\
\text { pressure } \\
\text { testing }\end{array}$ & 0.17 & $\begin{array}{l}\text { line of pressure } \\
\text { testing }\end{array}$ & 0,18 \\
\hline Bridge crossing & 0.49 & branch & 0.45 & branch & 0,49 \\
\hline $\begin{array}{l}\text { Elevated on high } \\
\text { support }\end{array}$ & 0.27 & $\begin{array}{l}\text { transition } \\
\quad(\text { cone })\end{array}$ & 1.9 & link & 0.2 \\
\hline $\begin{array}{c}\text { Elevated on low } \\
\text { support }\end{array}$ & 0.48 & direct site & 1.08 & $\begin{array}{l}\text { transition } \\
\text { (cone) }\end{array}$ & 0.35 \\
\hline Flowless channel & 1.09 & $\begin{array}{l}\text { the direct site } \\
\text { in a motionless } \\
\text { support }\end{array}$ & 1.1 & direct site & 1.05 \\
\hline
\end{tabular}




\begin{tabular}{|c|c|c|c|c|c|}
\hline Cellar & 0.43 & $\begin{array}{l}\text { the direct site } \\
\text { with the } \\
\text { welded mobile } \\
\text { support }\end{array}$ & 0,79 & $\begin{array}{c}\text { the direct site } \\
\text { in a motionless } \\
\text { support }\end{array}$ & 0,84 \\
\hline $\begin{array}{l}\text { Semi-flow } \\
\text { channel }\end{array}$ & 0.85 & $\begin{array}{c}\text { omental } \\
\text { compensator }\end{array}$ & 0.3 & $\begin{array}{l}\text { the direct site } \\
\text { with the } \\
\text { welded mobile } \\
\text { support }\end{array}$ & 0,8 \\
\hline Flow channel & 0.97 & $\begin{array}{c}\text { welded } \\
\text { connection } \\
\text { (welded seam) }\end{array}$ & 0.45 & $\begin{array}{c}\text { omental } \\
\text { compensator }\end{array}$ & 0,46 \\
\hline Adit & 0.62 & $\begin{array}{c}\text { bellow valves / } \\
\text { lenses } \\
\text { compensator }\end{array}$ & 0.51 & $\begin{array}{c}\text { welded } \\
\text { connection } \\
\text { (welded seam) }\end{array}$ & 0.57 \\
\hline $\begin{array}{l}\text { Baffle driving / } \\
\text { tunnel }\end{array}$ & 0.38 & air tap & 0.26 & $\begin{array}{c}\text { bellow valves / } \\
\text { lenses } \\
\text { compensator }\end{array}$ & 0.41 \\
\hline \multicolumn{2}{|c|}{ Average value 0.6} & tee & 0.27 & air tap & 0.34 \\
\hline & & \multicolumn{2}{|c|}{ Average value $0, .64$} & tee & 0.49 \\
\hline & & & & $\begin{array}{l}\text { the site in a } \\
\text { wall or on } \\
\text { border of the } \\
\text { channel }\end{array}$ & 0.3 \\
\hline & & & & $\begin{array}{c}\text { manometer } \\
\text { union }\end{array}$ & 1.17 \\
\hline & & & & \multicolumn{2}{|c|}{ Average value 0.47} \\
\hline
\end{tabular}

Table 3. Speed of external corrosion (average) according diameters

\begin{tabular}{|l|c|c|c|}
\hline $\begin{array}{l}\text { Diameter of a pipe, } \\
\text { conditional Diameter of the } \\
\text { P1 pipe }\end{array}$ & $\begin{array}{l}\text { Speed of } \\
\text { Corrosion of a P1 } \\
\text { pipe }\end{array}$ & $\begin{array}{l}\text { Diameter of a } \\
\text { pipe, equivalent, for a } \\
\text { P2 pipe }\end{array}$ & $\begin{array}{c}\text { Speed of } \\
\text { corrosion of a P2 pipe } \\
\text { [mm in a year] }\end{array}$ \\
\hline 50 & 0.3 & 50 & 0.22 \\
\hline 70 & 0.05 & 70 & 0.38 \\
\hline 80 & 0.29 & 80 & 0.36 \\
\hline 100 & 0.34 & 100 & 0.4 \\
\hline 125 & 0.26 & 125 & 0.22 \\
\hline 150 & 0.41 & 150 & 0.37 \\
\hline 200 & 0.63 & 200 & 0.63 \\
\hline 250 & 0.48 & 250 & 0.5 \\
\hline 300 & 0.7 & 300 & 0.75 \\
\hline 350 & 0.47 & 350 & 0.48 \\
\hline 400 & 0,86 & 400 & 0.86 \\
\hline 500 & 0.7 & 500 & 0.71 \\
\hline 600 & 0.71 & 600 & 0,5 \\
\hline 700 & 0.72 & 700 & 0.5 \\
\hline
\end{tabular}




\begin{tabular}{|l|c|c|c|}
\hline 800 & 0,47 & 800 & 0.52 \\
\hline 900 & 0,35 & 900 & 0.3 \\
\hline 1000 & 0,67 & 1000 & 0.96 \\
\hline 1200 & 1 & 1200 & 0.82 \\
\hline 1400 & 0.86 & 1400 & 1.16 \\
\hline \multicolumn{2}{|c|}{ Average value 0.54} & \multicolumn{2}{c|}{ Average value 0.56} \\
\hline
\end{tabular}

According to the data of the tables it is visible that the average value of the speed of external corrosion on the giving pipeline is $0.54 \mathrm{~mm}$. in a year, and on the return pipeline is $0.56 \mathrm{~mm}$. in a year. It proves the existence of potentially possible violations in the heating systems maintenance, which inevitably lead to the emergence of economic, environmental and social risks, influencing the conditions of the sustainable development and causing the need of acceptance of preventive measures. For this purpose the factors, influencing emergence of failures and damages of the heating systems were defined and quantitatively estimated (Figure 2).

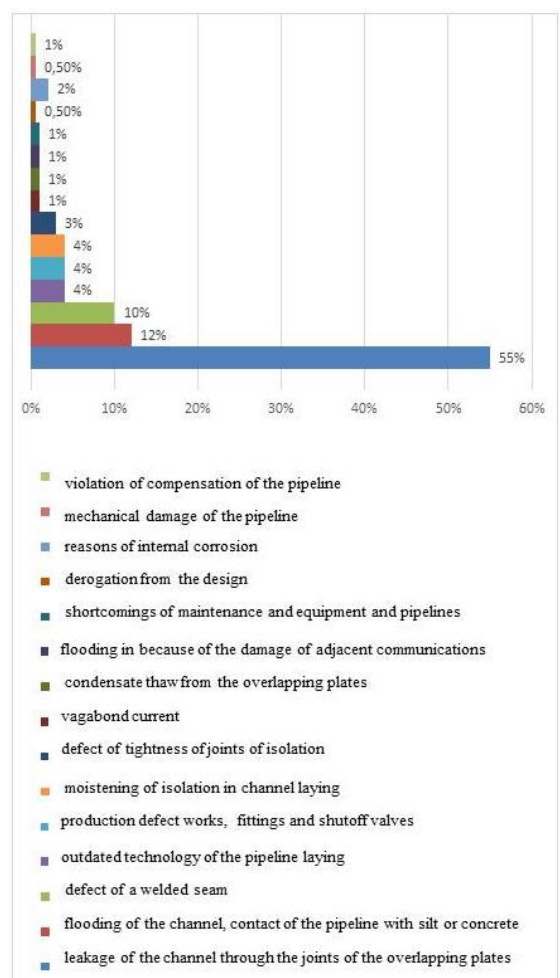

Fig. 2. The factors influencing the emergence of damages of heating systems

In the long term the classification of damages and failures according to their criticality is to be carried out according to normative and technical and (or) design documentation, on the basis of technical and economic reasons and reasons of safety. The level of the real and indirect relevant loss, connected with the failures can act as the criterion for the classification of criticality of failures for making managerial decisions in the context of sustainable development. 


\section{Conclusions}

Application of the standards of the EN 15643 series determines the need of definition of estimates of indicators of sustainable development, i.e. the estimates of ecological, social and economic indicators of a construction project, carried out at the same time in the same conditions, taking into account the same technical and functional characteristics of the estimated facility. The system of concepts and provisions of methodical approach, offered above will be in the uniform semantic field excluding contradictions in the wording of the obligatory and regulated requirements of information and analytical base of making managerial decisions on the sustainable development in the context of GOST. The main dominant of the configuration and contents, characterized within the offered methodical approach of information and analytical base for providing these requirements of GOST is the studied specifics of construction facility - the heating systems. Underground laying of engineering networks at a construction stage which causes difficulties at other stage of their life cycle - during the maintenance due to the existence of the factor of influence of surrounding soil and problematical character of access to engineering constructions in the course of their maintenance. The key aspect of the development of management of processes of sustainable development in the estimated prospect is the development of techniques of assessment of economic, ecological and social character according to GOST ideology on the basis of new quality of information provided with the offered information and analytical base on the heating systems maintenance.

In the whole management of processes of the sustainable development in the conditions of existence of three tendencies of perspective development of construction of the power supply facilities in the Russian Federation, it is important to provide a harmonious combination of the use of the traditional technical solutions and innovative developments, directed to the increase in functionality of thermal networks, based on new possibilities of financing of these directions of the development, created thanks to updating of the legislation on heat supply in our country. Further development of these ideas needs to be carried out in line with the accents, declared at the representative international forums, which orient management on «the human life; minimization of the damage caused to selfrestoration of the environment" in combination with "the optimum use of not renewable resources and constant application of renewable resources" as the results of steady construction [9].

\section{References}

1. The federal law "On heat supply", July 27, 2010 No. 190-FZ Russian newspaper, Federal release 5247-168 (2010)

2. The federal law "On introduction of amendments to separate acts of the Russian Federation, regarding enhancement of regulation of the rates in the sphere of electrical power supply, heat supply, gas supply, water-supply and water disposal", December 30, 2012 No. 291-FZ, Russian newspaper, 3 (2013)

3. The Instruction of the Government of the Russian Federation, "On the Concept of long-term social and economic development of the Russian Federation until 2020", November 172008 N 1662-r, Collection of the legislation of the Russian Federation", Federal release, 47, 5489 (2008)

4. The Instruction of the Government of the Russian Federation "On the Energy strategy of the Russian Federation until 2030", November 13, 2009 No. 1715-r Moscow, Collection of the legislation of the Russian Federation", Federal release, 48, 5836 (2009) 
5. The Resolution of the Government of the Russian Federation "On the approval of the list of the facilities and technologies, having high energetic performance which the implementation of investments into creation is the base for provision of the investment tax credit" July 12, 562 (2011)

6. Forecast of scientific and technological development of branches of fuel and energy complex of Russia until 2035", the Official site of the Ministry of Energy of the Russian Federation is approved by the Minister of Energy of the Russian Federation on October 14, 2016 [An electronic resource]. Access mode: https://minenergo.gov.ru/node/6365 (25.09.2018)

7. The state programme of the Russian Federation "Energy saving and the increase in the energetic efficiency until 2020" approved by the Resolution of the Government of the Russian Federation of December 27, 2446-r (2010)

8. The subprogramme 1 "Energy saving and increase in energetic efficiency of" the new state program of the Russian Federation "Energy efficiency and development of power engineering", approved by the Instruction of the Government of the Russian Federation of April 3, 512-r (2013)

9. The Kyoto Protocol to the framework convention of the United Nations on climate change. The official text in Russian, the UNO, (1998)

10. Project of strategy of heat supply. [Electronic resource]. Access mode: http://www.energosovet.ru/teplo_strateg.php (25.09.2018)

11. "Power Strategy of Russia for 2035" July 06, 2013 No. Pr-1471 (not adopted, "Oupdating of the Energy strategy of Russia until 2030" (2013)

12. National standard of the Russian Federation. GOST P 57274.1-2016/EN 1564312:2010 Sustainable development in construction. Part 1. General provisions. Electronic fund of standard and legal documentation (2010)

13. National standard of the Russian Federation. GOST P 57274.1-2016/EN 156431:2010 Sustainable development in construction. Part 2. Principles of assessment of ecological indicators (2010)

14. National standard of the Russian Federation. GOST P 57274.1-2016/EN 156431:2010 Sustainable development in construction. Part 3. Principles of assessment of social indicators (2010)

15. National standard of the Russian Federation. GOST P 57274.1-2016/EN 156431:2010 Sustainable development in construction. Part 4. Principles of assessment of economic indicators (2010)

16. ISO 15686-1:2011.Buildings and constructed assets. Service life planning. Part 1: General principles and framework. https://www.iso.org/ru/standard/45798.html?browse=tc (Access Mode: 25.09.2018)

17. ISO 15392:2008. Sustainability in building construction. General principles https://www.iso.org/ru/standard/40432.html (Access Mode: 25.09.2018);

18. EN 15643 [Digital resource] European Commission. Access mode: https://ec.europa.eu/eip/ageing/standards/home/other-home/en15643-32012_en (Access Mode: 9/25/2018);

19. B. Badaguyev, Operation of engineering systems (Moscow, Alpha Press, 2012)

20. N.G. Verstina, E.G. Evseev, A.M. Goncharov, Economy and business, 9 (74), 967-972 (2016)

21. N. Verstina, E. Evseev, MATEC Web of Conferences, Volume 193, 05007 (2018) DOI: https://doi.org/10.1051/matecconf/201819305007

22. T.A. Kapitanova, G.P. Struchkova, Science and education, 2 (2014)

23. D. Meadows, etc. Borders of the growth, in Russian (Moscow, MSU publishing house, 1991) 
24. M.X. Meskon, M. Albert, F. Hedouri, Management principles, in Russian (Moscow, LLC I. D. Williams, 2012)

25. Ministry of Energy of the Russian Federation [An electronic resource] Official site of the Ministry of Energy of the Russian Federation. Access Mode: https://minenergo.gov.ru/ (9/25/2018);

26. Russian Heat Supply non-profit Partnership [An electronic resource] Official site of NP Rossiyskoye teplosnabzheniye Access Mode: http://www.rosteplo.ru/nprt/ ( 9/25/2018);

27. A.R. Stanislavsky, Economics and Management of Innovative Technologies, Access mode: http://ekonomika.snauka.ru/2014/10/6049 (date of the address: 9/25/2018);

28. A.A. Black, Terra Economicus, 9, 2, 2, (2011)

29. D.A. Shmakova, Policy, state and right, 4 (2016) URL: http://politika.snauka.ru/2016/04/3804 (9/25/2018);

30. C.J.Kibert. Preface. In Proceeding of first International conference of CIB TG 16 on sustainable construction (Tampa, Florida, 1994) 